\title{
Who says waiting is boring? How consumer narratives within online communities help reduce stress while waiting
}

\section{¿Quién dice que esperar es aburrido? Cómo las narraciones de los consumidores en las comunidades online ayudan a reducir el estrés mientras se espera}

Mahmud Hassan

Department of Marketing, University of Queensland, Brisbane, Australia, and

Rumman Hassan

Department of Management and Enterprise, University of Southern Queensland,

Toowoomba, Australia

\begin{abstract}
Purpose - Waiting is associated with pain and stress that leads to frustration. However, consumer narratives may help cope with the stress associated with such waiting. This study aims to understand consumer waiting behaviours within online communities.

Design/methodology/approach - Data was gathered following a netnographic approach from a Facebook brand community (FBC) by downloading and archiving the threads related to members' waiting behaviours. This resulted in 91 pages of data, with 438 individual comments and 179 distinct threads.

Findings - The data revealed that members of the sampled FBC exercised waiting behaviour. The authors confirm that waiting for a product is associated with both negative outcomes (frustration, boredom, etc.), but positive ones (create stronger ties with the brand and fellow members, etc.). Members of the FBC exhibited reduced consumer anxiety and stress during the waiting period.

Research limitations/implications - This study found 13 waiting behaviours within the FBC and supports the idea that new value-creating behaviours are noticed within the context of FBCs.

(C) Mahmud Hassan and Rumman Hassan. Published in Spanish Journal of Marketing - ESIC. Published by Emerald Publishing Limited. This article is published under the Creative Commons Attribution (CC BY 4.0) licence. Anyone may reproduce, distribute, translate and create derivative works of this article (for both commercial and non-commercial purposes), subject to full attribution to the original publication and authors. The full terms of this licence maybe seen at http:// creativecommons.org/licences/by/4.0/legalcode
\end{abstract}

Received 16 January 2020 Accepted 18 August 2020
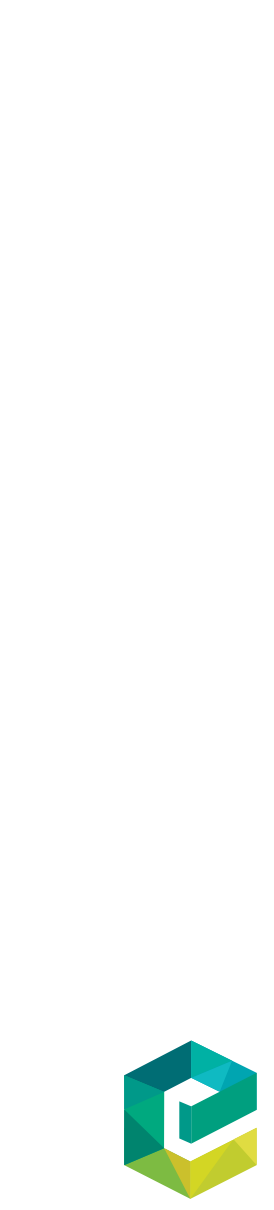

Spanish Journal of Marketing ESIC

Vol. 24 No. 3,2020 pp. $403-424$ Emerald Publishing Limited 2444-9709 DOI 10.1108/SJME-01-2020-0010 
Originality/value - This study focuses on waiting within a goods-based context (waiting to be served has been examined predominantly within the service sector). The study explored the behaviours of consumers who use social media to complain about extended waiting periods to receive the product along with other consumer reactions to these waiting crowds to reduce the emotional pain associated with such delays.

Keywords Facebook, Online communities, Waiting time, Consumer narratives, Netnographic approach

Paper type Research paper

\section{Resumen}

Propósito - La espera se asocia con el dolor y el estrés, lo que lleva a la frustración. Sin embargo, el relato de otros consumidores puede ayudar a hacer frente al estrés asociado a dicha espera. Este trabajo busca entender el comportamiento de espera de los consumidores dentro de las comunidades online.

Diseño/metodología/enfoque - Los datos fueron recopilados siguiendo un enfoque netnográfico de una comunidad de marca en Facebook (CMF) mediante la descarga de mensajes; sólo los hilos relacionados con los comportamientos de espera de los miembros fueron descargados y archivados. Esto resultó en 91 páginas de datos con 438 comentarios individuales y 179 hilos distintos.

Hallazgos - Los datos revelan que en Facebook se dan comportamientos de espera. Confirmamos que la espera de un producto no sólo está asociada a resultados negativos (frustración, aburrimiento, etc.), sino también a resultados positivos (crear lazos más fuertes con la marca y los compañeros). Además, se comprueba que los miembros de la CMF reducen la ansiedad y el estrés del consumidor durante el período de espera.

Limitaciones/implicaciones de la investigación - Este trabajo encuentra 13 comportamientos de espera dentro de una CMF

Originalidad/valor - Este trabajo se centra en la espera dentro del contexto basado en los bienes (la espera para ser atendido ha sido examinada principalmente dentro del sector de servicios). Además, no sólo nos centramos en los consumidores que utilizan los medios sociales para quejarse de una espera más larga en la recepción del producto, sino también en la reacción de otros consumidores a estas esperas para reducir el dolor emocional asociado a dicho retraso.

Palabras clave Tiempo de espera, Narrativas de consumidores, Comunidades online, Facebook, Enfoque netnográfico

Tipo de artículo Trabajo de investigación

\section{Introduction}

Time is a crucial life element and a scarce resource with significant economic value (Mogilner and Aaker, 2009). As the century-old proverb persistently highlights - "time is money". Within the field of consumption, time is regarded as a constraint in purchasing choice (Becker, 1965). The effect of waiting time and its relationship with customer satisfaction (Liang, 2019; Li et al., 2018; Bielen and Demoulin, 2007; Pruyn and Smidts, 1998) or product evaluation (Osadchiy and Diwas, 2017; Chien and Lin, 2015; Hui and Tse, 1996) has been examined extensively in the service context.

The internet has opened up the platform of online communities for an unprecedented level of customer-to-customer interactions (Akar et al., 2019; Priharsari et al., 2020; Casaló et al., 2011). Studies support that consumers are increasingly using social media to complain (Hassan and Casaló, 2016), e.g. to express their dissatisfaction with long waiting periods to receive products (Hassan, 2013). Even less recognised is the phenomenon of consumer reactions to these waiting crowds that reduce the emotional pain associated with such delays. Such a narrative entailing the behaviours of consumers devoted to a given brand towards the waiting crowd should reduce the stress related to waiting for a product and help them remain loyal to the brand. Therefore, there is both an academic and managerial need for an in-depth understanding of consumer waiting behaviours in social media and how consumers react to such behaviours. 
Consumers are often waiting to be served. For example, customers wait to be served in restaurants, banks, hospitals and airports. Similar waiting behaviour exists in a goodsbased context (e.g. waiting to receive a good). Typically, the waiting periods for goods is longer than the time typically waited to receive a service (a consumer may need to wait up to 12 months after pre-ordering a custom-made motorcycle). Such prolonged waiting may reveal various emotional responses that may not be observed within the context of service. However, it is astounding to notice that the effect of waiting behaviour within a goods-based context has received little attention. As such, this study explores consumers' psychological and behavioural response with regard to waiting in the goods-based context.

To shed light on these issues and contribute to the literature, the present research endeavours to achieve the following goals:

- Examine consumers' waiting behaviour in virtual brand communities.

- Identify how consumers' cope with the stress associated with frustrations during lengthy waits.

- Explore other members' behaviours towards the grieving consumers waiting extended periods to receive their goods.

- Explore new waiting behaviour that may be noticed within a goods-based brand community context. Because of the lengthy wait within goods context, we anticipate that it will reveal varied emotions that are not prevalent within service context.

To achieve the aforementioned goals, this study focuses on Facebook brand communities (henceforth referred to as FBCs) because this is the leading social networking, site with many companies maintaining brand communities on Facebook (Hassan and Casaló, 2016). The paper elaborates how other members' engagement can make waiting entertaining and gratifying. By taking excerpts from FBCs, we show how other members comfort and persuade the frustrating crowd and ask them to stick to the brand. This is a major breakthrough in the context of waiting behaviour, as previous studies (Liu et al., 2018) mostly suggested that delays lead to consumer frustration, boredom and cancellation of purchase.

The remainder of this work is structured as follows. First, we briefly review the literature on waiting time and discuss the research questions. Then, the methodology used in this research is explained, followed by the major findings. The paper concludes by discussing the implications of the study, its limitations, and future research opportunities.

\section{Conceptual background}

\subsection{Waiting time}

Time is a critical aspect of modern human life. In choosing a product, consumers weigh the benefits against money, effort and psychic costs of buying and using it. The time spent in obtaining the product is also a significant consideration. As waiting for a product stands between customers and the accomplishment of desired goals (Liang, 2019; Hui and Tse, 1996), one may feel helpless when waiting an unspecified period (Chen and Jia, 2012; Rafaeli et al., 2002).

Waiting time is the amount of time a customer has to wait to receive a product or service. Waiting time or delays have adverse effects on the overall service evaluation (Stidham, 2009; Taylor, 1995), whereas an effective response to the wait influences the service satisfaction (Li et al., 2018; Hui and Tse, 1996). Within the retail context, waiting is perhaps the most 

In services marketing, various strategies were proposed to tackle waiting crowds, i.e. shortening the queue size (Pruyn and Smidts, 1998), making waiting times more enjoyable (Liang, 2019; Pruyn and Smidts, 1993); fairness in queue setup (Taylor, 1995); improving the waiting environment (Usunier and Valette-Florence, 2007; Baker and Cameron, 1996); using time fillers while waiting (Antonides et al., 2002); providing information to waiting consumers and asking them to reserve early (Lovelock and Lapert, 1999). However, to date, studies have predominantly considered waiting behaviour within service-based scenarios. The present study extends consumer waiting behaviour by considering product-based waiting scenarios as an important and overlooked research agenda in the context of waiting behaviour.

Studies on waiting behaviour show that consumers are often willing to accept delays of days, weeks, months and even years to maximise rewards (Paglieri, 2013). However, while waiting, individuals may become impatient and abandon the product/service (Li et al., 2018). To this end, Osadchiy and Diwas (2017) demonstrated that customers are less likely to purchase a product/service if they entail protracted delays. Based on the studies of four different population samples, Liu et al. (2018) found that consumers prefer shorter appointment delays, flexibility in appointment times and shorter in-clinic waiting when scheduling medical appointments. Furthermore, Mitsutomi and Kobayashi (2012) set the hypothetical waiting situation and investigated whether situational variables such as the value of the object, waiting place and waiting time influenced the waiting behaviour. Their findings suggest that waiting results in an increase of frustration, causing the person to lower the value of the object. Consequently, the person is more likely to stop waiting when the value of the object reduces. While these studies contributed significantly to the waiting behaviour literature, we are yet to understand how the behaviours of online community members influence the waiting crowd. Hence, how other consumers respond to the waiting crowd to reduce the anxiety associated with wait is currently unknown. By taking FBCs as a context, this study examines how other members persuade the waiting members, show empathy to the waiting crowd and narrate vivid stories to encourage the waiting consumers to remain patient and loyal to the brand.

\subsection{Waiting behaviours in Facebook brand communities: research questions}

Our research focuses on the following three research questions regarding members' behaviours while waiting within FBCs and how fellow members react to them:

RQ1. Do members complain while waiting within FBCs?

RQ2. Do members within FBCs engage in various behaviours to cope with the frustration of lengthy waits?

$R Q 3$. Do fellow members engage in value-creating activities to help waiting consumers within FBCs?

First, it is a well-established phenomenon that consumers experience negative emotions when products fail to meet expectations (Li et al., 2018; Mano and Oliver, 1993). Extant research also indicates that waiting times or delays in receiving the product leads to frustration (Aksin et al., 2013; Chebat et al., 1995). Moreover, waiting is one of the major contributors to consumer complaints (Chien and Lin, 2015). In this regard, Liang (2019) suggested that members usually calculate the perceived value and tend to complain more when they expect a high amount of benefits from complaining. Furthermore, negative 
word-of-mouth in social media is a means of expressing dissatisfaction with a product or service (Einwiller and Steilen, 2015).

The equity theory helps explain this behaviour by explaining how people act upon a perception of inequity (Steenhaut and Van Kenhove, 2005). Waiting may cause the consumer to under-benefit, and the consumer might try to restore equity in his/her relationship to the brand in subsequent periods by diminishing the benefits of the brand (e.g. by complaining and spreading his/her dissatisfaction) or trying to over-benefit from the brand by complaining. Thus, members of FBCs may think that if they complain about their delay, the brand would take steps to rectify the situation as they do not want to tarnish the image of the brand within such online communities. If not, the complainant can spread the consumers' dissatisfaction and potentially achieve support from other dissatisfied consumers (Einwiller and Steilen, 2015). Therefore, we expect that members' complaints of waiting will be apparent within FBCs.

Second, research indicates that waiting times or delays in receiving the product leads to frustration, irritation and boredom (Liang, 2019; Chebat et al., 1995). A frustrated individual engages in behaviours to cope with the stress of waiting in private and public domains (Berkowitz, 1989). Similarly, FBCs' members frustrated with lengthy waits should also engage in behaviours to cope with their frustrations by, e.g. initiating negative word-ofmouth, or switching brands (Schiffman and Kanuk, 2014). Many of these FBCs have millions of members who interact on a daily basis and share various emotions with regards to personal experience (Dunay and Krueger, 2011). In this regard, we suggest that as member complaints are apparent within this virtual sphere, many others will display coping behaviour with such frustration within FBCs. This may be explained by the equity theory, as coping behaviours may help restore equity in the brand-consumer relationship. Hence, we expect that FBCs members will engage in behaviours to cope with the frustration of lengthy waits.

Finally, brand communities add value-creating behaviours within the customer-tocustomer context. In this regard, the customer is no longer regarded as a passive receiver but an active and knowledgeable participant in the common value-creating process (Pagani et al., 2011). Furthermore, Marandi et al. (2010) contend that Facebook users have, from the beginning, co-created not only value but also defined value in new ways. Various studies also confirm such behaviour within the customer-to-customer context. For example, they help disseminate information (Priharsari et al., 2020), recommend the brand to fellow associates (Casaló et al., 2011; Muñiz and Schau, 2005), persuade consumers to purchase the product (Kozinets et al., 2010), create ongoing relationships with other members (Frasquet-Deltoro et al., 2019; Andersen, 2005), empathise with other members (Schau et al., 2009) and make these consumers feel a part of the brand (McAlexander et al., 2002). In the context of brand communities, several authors have found that fellow members help other members probably because they share a common interest (i.e. the passion for the brand; Muñiz and O'Guinn, 2001) and think other members may reciprocate their efforts and help them if needed (Wiertz and De Ruyter, 2007).

Following the equity theory, reciprocity would serve to make the perceived contributions and benefits of the community members psychologically consistent (sometimes, help is received, and other times, help is given back), leaving members neither under- nor overbenefited and ensuring ongoing help among members in the community. As a result, such value-creating behaviours to help waiting consumers should be apparent within FBCs. Hence, we expect that fellow members will engage in various value-creating activities for the waiting consumers within FBCs. 
SJME

24,3

\section{Method}

To address the research issues, we examine the online waiting behaviour in its natural setting using a qualitative approach and a relatively new research technique called netnography (Kozinets, 2011). Our research approach aims to generate scientific propositions about this old phenomenon within a new context that can be subject to further testing and verification. Kozinets' (2011) guidelines for netnography were followed to ensure a rigorous research approach. Regarding the selection of the communities to be analysed, Kozinets (2011) recommends looking for online communities that are:

- relevant - they should relate to the research question;

- active - they should have recent and regular communication;

- interactive - communication should occur between participants;

- substantial - they should have a large number of communicators and an energetic feel;

- heterogeneous - they should have a number of different participants; and

- data-rich - they should offer detailed data.

Based on these criteria, Ford Fiesta's FBC site is selected. Ford Fiesta was introduced in the North American market in 2010, and Ford used the internet and its Facebook site to promote and launch the new vehicle. Because of such effort, enormous hype was created within its consumers who were highly engaged through the site. Furthermore, the brand manager of Ford Fiesta was looking after the site and participated in various discussions regularly. Members from all around the world shared their feedback and suggestions, consumption experience, issues with the brand and various other emotional and cognitive responses on its Facebook site, thereby making it a vibrant place for communication and information sharing.

This forum was deliberately chosen not only because it fulfils the relevant criteria, but also because it spans different topics, interest groups and languages, thereby maximising the validity of the study. Furthermore, the Ford Fiesta FBC had 246,176 members when the research was conducted, and today, has more than 780,000 members. Non-members can see all posts, but membership is required to post in the forum and to send personal messages. Membership can be achieved by clicking the Like option within the Facebook page. Because of such initial efforts, many consumers' pre-ordered their Ford Fiesta (approximately 3,000 down payments (Korzeniewski, 2010)). Furthermore, a dealership quota of 4,000 plus dealers made the initial production strained and fatigued. As a result, many consumers had to wait up to ten months before getting the product, subsequently making them frustrated and dissatisfied.

Research for this study is undertaken covertly without taking part in any discussion. By not posting on the threads, the integrity of the discussions was preserved within the forum, as members' behaviours tend to change upon understanding that someone else is watching them (Bryman, 2008). We examined the brand communities looking specifically for posts concerning waiting related issues. Within such posts, we also looked for other consumer responses, particularly how they deal with issues associated waiting. Emphasis was given to locating the responses and messages of associates who have recently received the product after a lengthy wait. The volume of downloaded texts amounted to 91 double-spaced, 12-point type size pages, which represents 438 postings containing 179 distinct threads and 23,529 words in total. The downloaded messages were posted between April to November 2010. 


\subsection{Coding process}

All the downloaded messages were copied on paper, and every message was read several times to identify the members' waiting behaviour and relevant threads that indicate the responses to such behaviour. The data coding process was carried out manually to ensure quality and consistency, and constant emphasis was made to look for new themes that may emerge from the textual data (Miles and Huberman, 1994). To this end, several procedural steps took place. To start, a sample of downloaded messages from the FBC site was printed, and each message was read to identify the codes. Messages or responses that were not adding to or directly relevant to the waiting behaviour were not coded. Messages that referred to several different themes were coded for each theme (Spiggle, 1994). Codes were highlighted and written within the text. New themes emerged as the coding process progressed, and all were given a separate name that included the coding frame, which became part of the broader analysis.

The same textual data were then examined a second time. Three important aspects were considered during this period. First, all new themes were compared with already coded instances to determine if the new instances belonged to an existing category. Second, special attention was given to the messages that were not coded during the first phase so as to determine if they belonged to any of the new codes or to existing codes that were possibly overlooked. Third, consideration was given to identifying the core meaning of messages that generated several codes. Here, the messages were read several times to identify which of the various codes represented the message most accurately, and each message was assigned a single code. Using this process, the researcher sought to interpret the underlying messages conveyed to other community members. To reduce the impact of previous ideas on subsequent data coding, a month-long break was taken before coding the second set of data. The codes developed in each set were matched to ensure consistency within the coding process (Miles and Huberman, 1994).

The analysis resulted in a clear set of coding procedures, and subsequent work was performed using an iterative style focused on preserving the authenticity of the posts (Glaser and Strauss, 1967). The members whose messages are used as a quote for this research have been given a pseudonym to protect their identities. The first letters of their names are used along with their gender, which is denoted as $(\mathrm{M})$ for male and $(\mathrm{F})$ for females.

\section{Findings}

This section shows the results regarding: common complaining behaviours in FBCs while waiting (answering RQ1), behaviours to cope with the frustration while waiting (answering $R Q 2$ ), value-creating behaviours within customer-to-customer context (answering $R Q 3$ ) and new behaviours that have not been apparent in previous literature (answering $R Q 3)$. In sum, this research identifies 13 themes of waiting behaviours in the Ford Fiesta FBC.

\subsection{Common behaviour while waiting}

4.1.1 Whining. Waiting is associated with a negative evaluation of the product's performance. The following post indicates how members form negative emotions after a product delay.

NWC(F) Ford canada you suck! you continuously make promises that are not being kept and I'm really very tired of being expected to just wait [. . . ] my car is still sitting on the ramp in Mexico?? i would really like to know WHY the heck its not on its way to my dealership five months after being ordered, 3 months after being built, 2 months after the first promised ETA, 2 weeks after leaving the factory and now im being told it could be ANOTHER week 
SJME

24,3

after my second ETA? How many more "weeks" do u expect me to wait? ITS A BIG DEAL!!! 3 August 2010 at 8:36 p.m.

Marketing shapes consumer expectations. Constantly breaking such promises decreases confidence in the brand. NWC(F)'s comment indicates how dissatisfaction through product delay is resulting in intense negative response (Liu et al., 2018; Hui and Tse, 1996). Furthermore, she is frustrated with the continuous failure to meet the marketed promises. Such negative feelings are common within FBCs as Ford could not deliver the product on time with many pre-ordered consumers forced to wait long periods to receive the product. This is consistent with studies (Liang, 2019; Pruyn and Smidts, 1998) that contend that during waiting times, customers may exhibit intense negative emotional responses, such as irritation, boredom frustration and stress.

\subsection{Behaviours to cope with the frustration while waiting}

4.2.1 Quitting. The data further shows that some customers intend to leave the brand if they have to wait long times to obtain the product. The following excerpt shows how members consider purchasing from a competing brand when the waiting period exceeds their expectations:

MGV(M) Ford Fiesta, why is there a quality check in Baltimore when my car had been sitting in a lot in Mexico outside the plant for over 2 months? I would have thought the checks would have been completed then and there before loading it on the boat. Now I am an unhappy customer again and am not having the Fiesta Experience I was expecting. This nightmare continues and this $\$ 50$ gift card has yet to arrive which does no justice for my wait. I hope you will have answers soon because I am so close to buying a Kia. 25 August 2010.

MGV(M)'s comment shows that delays significantly influence feelings of anger and have an adverse psychological effect where consumers face uncertainty about the wait length and experience significant stress. MGV(M)'s comments further indicate that the experience is turning him to buy a competitor's product. Such findings confirm Osadchiy and Diwas (2017) suggestion that waiting leads to greater complaints, and consumers may quit the brand because of such lengthy waits (Lovelock and Gummesson, 2004).

4.2.2 Gossiping. Members of the waiting crowd may spend significant portions of their time speculating the cause of the lengthy wait. Such sensational discussion may enhance community involvement and reduce the pain associated with prolonged waiting.

MS(M) Some in Ford forums have opined that the reason Fiestas are being held up is due to a camshaft gasket oil leak problem. It is only supposition, of course, but is floating around the "net as one possible reason. 16 October 2010.

Members within these virtual communities engage in transmitting sensational news dedicated to scrutinising the reason behind such a cause. The mutually interesting information conveyed through such gossip (not malicious though) may help the associates reduce the boredom related to prolonged waiting. Such gossiping within the virtual sphere indicates that it is an important form of social communication that serves to bond people (Kozinets et al., 2010). Perhaps, gossiping for goods-based products while waiting within FBCs is a strategy similar to using time fillers in service settings (Antonides et al., 2002), which should help reduce the boredom associated with lengthy wait (Paglieri, 2013; Zeithaml, 2002). Furthermore, by taking part in such a lengthy discussion, members may forget the brand's transgression and focus on broadcasting stories like this.

4.2.3 Fantasising. If the product in hand has a special meaning to someone, the associated wait may bring various emotions. Such is the case in the following excerpts, where members fantasise about the brand while waiting. 
MS(M) [...]. The Fiesta is the lunch bag you open, expecting what you expect, only to find an entirely different slice of something between two slices of bread you've never tasted before. It is that look on your sister's face when she knows she's gotten away, once again, with slapping you without your mum seeing it. Ford have, in a stroke of pure genius, produced that little pony you never got when you were a kid.

I find myself eagerly awaiting the day when I see my first Lime Squeeze 5-door SES Hatch with Cashmere Leather seats and those ultra-fashionable 17" pony shoes they have in the UK holding it all up. And when I say "it" should be glorious, like my red metallic Corolla with its deep charcoal grey exterior, "it" is all right. "It" is fine. "Fine", like the fine you never, ever say to someone when they ask you, "How do I look".

Little green Fiesta, I'll be waiting for you. I'll be the one climbing out of an Italian-styled sedan with a look that say's I'm, well, "fine”. 23 September 2010 at 11:07 a.m.

Sometimes, members vividly mention stories and detailed accounts of fantasising that arise from lengthy waits. The description of such daydreaming indicates an extraordinary attachment and a feeling of warmth attached to waiting (Oettingen, 2012). Such passionate encounters of daydreaming reiterate their imaginative pursuit and entertaining ideas about consumption as expressed through fantasising (Fournier and Guiry, 1993). Such passion disguised in the form of fantasising should help the consumers form a positive attitude towards the brand (Fournier, 1998) and help the waiting crowd remain patience a little longer.

4.2.4 Loving. Waiting behaviour within FBCs may involve sweet and sensational feelings for someone who is purchasing the product for the first time. The overwhelming positive emotion related to such a wait may outshine the pain associated, as seen in the following excerpt.

BB(M) the Ford Fiesta is going to be my first car. I've been driving my parents "99 bug for the past few years while saving up. In July I went to my dealership and ordered a red SES with all the goodies. Still waiting for the little bugger to get here even though its been on the inventory of my dealership's site since the beginning of July. Seems to keep getting pushed back and the wait is killing me! Dealer called yesterday to tell me it should be in this Sunday or sooner [. . . ] but personally I can't trust the ETAs anymore! Anyways, I can't wait to drive in my first car and I'm so happy its going to be a Ford:) 11 August 2010 at 11:08 p.m.

The emotion associated with purchasing the first car is irreplaceable and may contain extraordinary feelings. This is perhaps akin to one's first love. Such love may invoke feelings that are deep, tender and rewarding (Hochschild, 1979); hence, the wait associated with first car may also inhibit astonishing levels of passion. BB(M)'s remark - I can't wait to drive in my first car and I'm so happy its going to be a Ford - indicates a positive and eager passionate emotional response associated with the wait. Such findings confirm Belk et al.'s (2003) indication that if a consumer is passionate about a brand, he/she will engage in a much more emotional relationship with it and even feel a sense of loss when the brand is unavailable.

4.2.5 Justifying. Delays are associated with a variety of psychological states of mind. To reduce the negative feelings associated with delays, many consumers justified their decision publicly.

$\mathrm{MB}(\mathrm{M})$ There is one good thing about this wait (two more weeks for my pre order). I was able to do a little more research and found out that I am eligible for incentives to the tune of $\$ 1750$ ! Maybe with a little more digging, I'll save even more scratch. The only thing better than buying a new car is saving money while buying a new car =-D; 2 July 2010.

Such use of justification to resolve the guilt associated with the decision indicates that the waiting crowd practices rationalisation. Such obsessive-compulsive behaviour that deploys 
rationales behind the reason for the decision (Schau et al., 2009) should help reduce the tension associated with it. By pre-ordering, many consumers thought that they would be the first ones to use and show off their vehicles. However, as the delay caused them to wait for a longer period of time, public justification was necessary to validate their decision to wait (Simonson, 1989).

\subsection{Value-creating behaviours within the customer-to-customer context}

4.3.1 Informing. During the prolonged wait, many members were searching for information to locate the whereabouts of their vehicle. In such a scenario, fellow associates helped stranded consumers by providing information to help locate the product.

Initial comment: $\mathrm{SM}(\mathrm{F})$ I have also ordered one and i am wondering how you know where it is and when it was built/shipped? Is there a website that we can use to track the order and, if so, where do you get the order \# or whatever information you need to track it? Thanks! 27 August 2010.

Response: SW(F) SM get the vin \# from your dealer then you have two ways to get what's happening to your car. First you can call the 4 m's at 1-800-301-8348 with your vin \# they can give you updates. Second ask your dealer to print out the full visibility report [...] on your car it will give you info on every move your car has done, 27 August 2010.

SW(F)'s response shows how members of FBCs aide the stranded consumer stuck in a unique consumption experience. During such a lengthy wait, even the dealers were confused about the car's exact location and hence responded to the consumer's inquiry with caution. Other members who went through a similar situation shared information to help these stranded patrons. This validates Raban and Rafaeli's (2007) suggestion that online communities act as self-organising systems of informal learning, which allow members to interact and learn together by engaging in discussions and information sharing. Compared to offline contexts, offering help online is easier as people can do so in their own time and convenience (Sproull et al., 2005). This is perhaps the reason why such behaviour is evident even when consumers are waiting for the product in FBCs.

4.3.2 Counselling. Many of the comments within FBCs indicate that members provide detailed instructions to stranded members. This sort of comprehensive answer should help the abandoned member know what needs to be done to fix the problem, as seen within the following excerpt.

Initial comment: SZ(F) Ordered my Fiesta August $13^{\text {th }}$ and still don't have a VIN or ETA from the dealer. In fact, they are ignoring my calls. Seriously thinking of swallowing my deposit and finding something else. 2 September 2010

Response: JH(M) SZ, I was in a similar situation, and maybe I can offer a bit of advice. I ordered mine August 6 and was told I'd only have to wait a couple days or a week at the most. Three weeks later, after hearing repeatedly that I'd receive my car "any minute now," I asked the dealership if they could find a similarly equipped Fiesta at another dealership. They found one within 15 minutes, and it was only about an hour away. The substitute was a different colour (Magenta) than what I had originally ordered (Black) and it had a $\$ 350$ front armrest installed, but I accepted the deal. Turns out I'm in love with the Magenta and I don't know what I would've done without the armrest. Have you considered asking your dealer to find you a suitable Fiesta elsewhere? 2 September 2010.

Feedback to those consumers stuck in a unique consumption situation may relieve the stranded member of the pain they are experiencing. $\mathrm{JH}(\mathrm{M})$ was in a situation similar to Stephanie, and hence, his real-life suggestion with explicit information should help the forsaken consumer know what needs to be done to resolve their predicament. Such detailed feedback entailing specific action should help the stranded member resolve the situation 
(Yen et al., 2011). Social networking sites (SNSs) proved to be an important aspect of getting feedback from loyal consumers who view these brands as part of their lifestyle (McAlexander et al., 2002) and consistently provide ideas to upgrade the situation of other members (Akar et al., 2019; Hassan and Casaló, 2016).

4.3.3 Motivating. On Facebook, sometimes members try to persuade fellow associates who want to abandon the brand because of the prolonged wait. Such passionate comments have a positive effect on the complainer, as seen in the following excerpt.

Initial comment: JN(F) I am tired of waiting for my Fiesta. I ordered in February, my car was done June 1st, and it is still waiting to ship. If Ford can't manage to get all the early reservations to the customers before the dealers get general vehicles, they don't know how to manage their business. My family is a Ford family, my grandfather worked at the St. Paul plant, but I am seriously contemplating cancelling my order due to company mismanagement!!! 21 July 2010.

Response: $\mathrm{MD}(\mathrm{M})$ Crap, you waited this long, why give up now? These things are beginning to get delivered so why quit this close to the finish line? I'd be ticked off too but be patient. In any given situation in life a lot of time the only thing you can control is yourself and another thing - Wait until you have to deal with government and corporate beauracracies in life. It will make this little delay seem like waiting for Christmas. 21 July 2010.

There is increasing recognition of the importance of message characteristics, including both rational and emotional dimensions, along with the use of words, content and expressiveness in persuasive messages (Sweeney et al., 2012). MD(M)'s passionate remark reiterates the convincing nature of persuasive expressions within online communities. MD (M)'s fervent comment depicting a rational perspective and real-life advice should help the complainer take the right decision and not deviate from the purchase. Such findings strengthen Mazzarol et al.'s (2007) suggestion that the strength of advocacy relating to the intended power in delivering the given message plays an important role in persuading consumers. More importantly, as these citations are free of commercial self-interest, they are perceived to be more honest than company initiated information (Akar et al., 2019; Casaló et al., 2011).

4.3.4 Caregiving. Delays are associated with negative feelings towards the brand and causes consumer dissatisfaction. However, compassionate messages by associates during such times help reduce the grieving party's emotional pain, as seen within the following excerpt.

Initial comment: JI(F) So Ford is having some trouble shipping the Fiestas because of the bad weather. They even said it would be about a 10 day delay. Well its been 3 weeks now and no one at the dealership is giving me a straight answer. Really getting tired of the wait X/8 August 2010.

Response: $\mathrm{AM}(\mathrm{F})$ I feel your pain! I was supposed to have mine not this past Thursday, but the Thursday before. Every time I call to ask what is going on I either get an "it'll be here tomorrow for sure” answer, which it obviously isn't since I am still fiesta-less or no one returns my call. Frustrating! Hopefully all the frustration will melt when I finally lay eyes on my fiesta today?;) 9 August 2010.

The message posted by $\mathrm{AM}(\mathrm{F})$ should make the mourner feel that she is not alone in such a situation. By uttering the words "I feel your pain" - AM(F) is lending her shoulder to comfort the grieving party. Such findings lend support to Weiner's (1980) suggestion that it is easier to feel empathy for someone who is not responsible for his or her plight. As members who pre-ordered a new automobile experienced lengthy waits and complained on Facebook, many other members came forward to show empathy to the grieving member 
given that they are innocent victims. This study further contends that such empathetic messages should generate harmony between the members and help create a memorable experience, especially during such unpleasant times.

\subsection{New behaviours not previously reported}

4.4.1 Fearing appeal to the waiting crowd. Advertisers commonly use fear to motivate and induce various behaviour. In FBCs, other consumers used a similar approach to the waiting consumers to encourage them to remain loyal to the brand.

$\mathrm{KD}(\mathrm{F})$ I'll be honest, maybe I had a bad experience but I considered waiting for the Fiesta and went with the Fit Sport instead and I kind of hate it. Bad time with the dealer and car developed door and dash rattles at 100 miles (which Honda won't fix because it's "acceptable" noise). I'm almost considering selling it off and getting a Fiesta and taking the $\$ 2000$ hit or whatever [...]. 11 August 2010.

Fear is a powerful persuader that is commonly used by advertisers to influence their target audience. $\mathrm{KD}(\mathrm{F})$ 's message indicates that such behaviour is applied by associates to persuade waiting crowds considering changing brands. Consistent with Herr et al. (1991), we further propose that vivid information like this, which is inherently interesting, thoughtprovoking or attention-drawing is more accessible in memory, weighs more heavily in cognitive judgement and has more impact on judgements. In this regard, we contend that such a plea through a real-life example of a terrorising ordeal should deter members from making such a costly mistake.

4.4.2 Defending. In FBCs, some consumers blame the manufacturer for not delivering the product on time. In such a situation, some members started putting the blame on uncontrollable natural hazards to defend the brand against complaints.

MY(F) I ordered one in May and the delivery was supposed to be in late June [...]. What happened was that during the shipment, a hurricane in Mexico stopped a rail road and all the cars in that train had to revert back to Mexico. That caused other shipments delayed. Unfortunately, many people in dealersihp didn't know what was going on until the news was confirmed. It was worth waiting though. 15 September 2010.

SN(M) from a VERY reliable source: The mail rail line out of Cuautitlan Mexico was damaged by a tropical storm. As you all know, Mexico's infrastructure isn't, well, very good (it sucks a**). Once the rail line is fixed, Fiestas will be all over the place. 31 July 2010.

Both these comments in response to the complaints are interesting, as they try to tackle the situation by putting the blame on uncontrollable features (it is not Ford's fault, rather the hurricane or the tropical storm is to blame for such delays). It is fascinating to note the members clearly point out that such natural hazards can ruin any well-organised planning. Such findings indicate that today's consumers engage in behaviours to defend and offset the negative remarks (Colliander and Wien, 2013) of a frustrated waiting member within FBCs. This is an extension to the current notion that to dampen the negative effects of any harmful remarks by consumers, marketers engage in public relations efforts (Levesque and McDougall, 2000) that help restore the positive image of the brand (Wu, 1999).

Within FBCs, members complain about not receiving the product on time. In such occasions, members defend the brand's decision by citing facts and figures to deter the complainer as seen within the following excerpt:

MM(M) It's a steady roll out and the dealers will be populated in the coming weeks. Thinking about the logistics [... II think there are around 4,000 Ford dealers in the US. So if you're thinking of getting at least one to each dealer plus filling [. . . all the pre-orders [...] you're talking about producing $6,000+$ cars in a limited time span. Certainly explains the bit of backlog people are seeing with the recent orders [... I'm sure Ford will have the plant 
turning full tilt for a good long while. Although I was upset when they missed the mark on the delivery dates I believe they will be delivered with the highest possible quality. I'm glad Ford has enough pride to hold cars a little longer and make sure everything's perfect instead of them just being on time. Basically, I'd rather them be fashionably late than show up on time with their hair wet and no makeup. 18 and 28 June 2010.

MM(M)'s comment "you're talking about producing 6,000+ cars in a limited time span. Certainly explains the bit of backlog people are seeing with the recent orders" explains that it is not the fault of Ford Fiesta, rather the overwhelming interest in the brand within such a short time is to blame for the delay. MM(M)'s confidence with the brand entails a passionate member's level of trust in the brand (Pimentel and Reynolds, 2004). Such an avid account detailing conviction in the brand should ensure waiting consumers regarding the long-term reliability of the car and help them remain loyal to the brand. Such behaviour confirms the current notion that new value-creating behaviours are apparent within these online networks (Hassan and Casaló, 2016).

4.4.3 Cheerleading (reassuring the waiting crowd). Marketers undertake various strategies to tackle the waiting behaviour by trying to reduce the level of stress associated with waiting. Members vividly narrate stories to reassure the waiting customers and motivate them to stick to the brand.

SD(M) Figured this place would dig this [. . . ] so my girlfriend and I are running errands Friday night (in the Fiesta of course). We're leaving one of our destinations and in the parking lot sits the VW GTI stalking the Blue Fame beauty sitting in the back side of the parking lot. The best part is they didn't see us walking up to the car and when we went to unlock the doors and the lights flew up, the startling encounter revealed their lustful desire for a cheaper, more fuel-efficient, and better-looking car. They then zoomed off the lot in an attempt to cloak the reality they were just caught "checking out" the Fiesta.

I'm not much for gloating (though I'd completely understand if you didn't believe that after this post), but Ford should be proud of the product out there. People are taking notice and I couldn't be happier with the little car, even if it did take 6 months to get the keys. 11 October 2010.

Studies (Thompson et al., 1994) considered consumers as "self-narrators" whose stories impose a meaningful historical order onto life events and who selectively highlight particular facets of these experienced events in their narratives. Such narratives and stories of consumption experiences are abundant in the virtual community sphere (Schau et al., 2009). Members' vivid expressions of superior post-purchase practice to create a lust within the waiting members' eyes indicates such a narrative is shared within FBCs. These members relay vivid stories of consumption experience to cheer the waiting consumers. Such stories depicting members' superior product experience following the long wait should reduce the anxiety and stress of the associates waiting for the product. Studies (Jones and Peppiatt, 1996) suggest that reducing anxiety and stress during such periods make waiting seem shorter and comforting.

Waiting is always painful, especially when it is for a brand that has built up so much hype around it. Hence, the customers who pre-ordered these cars and find themselves waiting are reassured of the success stories of fellow members, which helps them remain patient and loyal longer.

MW(M) I just picked up Metallic Magenta SE Ford Fiesta Hatchback from Charles Gabus Ford. Just look at her, ain't she sweet. I reserved her back in October and picked her up Wed. Night July 14th. She was worth the wait let me tell you, she is a quiet, comfortable, fun, and sweet ride. She just isn't your normal sub compact car, she is so much more! I am just having 
SJME

24,3

416

a blast. I have a little over 200 miles on her and am averaging $41.2 \mathrm{mpg}$, how sweet is that? Her engine is not even broken in yet. Thank you Ford [ . . .], I am thrilled. 17 July 2010.

"She was worth the wait" - is directed to the frustrated crowd who had been waiting for a long time and wanted to give up. MW(M)'s expression is followed by his experience with the brand - She just isn't your normal sub compact car, she is so much more! I am just having a blast - should make the waiting members feel that it is sensible to wait for a product like this. This flamboyant story is directed to the waiting members who need a bit of lift to cheer them up and reduce the level of stress associated with waiting. By doing so, these members try to increase the value of the product. Studies (Osadchiy and Diwas, 2017) suggest that customers tend to wait more for a valuable product (Table 1).

\section{Discussion and implications}

Using the automobile industry as a context, we have unearthed 13 consumer waiting behaviours within FBCs. At first, the nature of existing waiting behaviour is noticed, confirming that waiting is associated with frustration and boredom (Osadchiy and Diwas, 2017; Hui and Tse, 1996). This may be a threat to companies, especially if other dissatisfied consumers join the complaint (Pfeffer et al., 2014). Further analysis revealed that members engage themselves in various emotional behaviours to cope with the stress associated with long waits. Consumers engage in brand switching, gossiping, engross in daydreaming, elaborate their first love encounter and rationalise during such lengthy encounters. Such behaviours may reduce the boredom associated with lengthy waits (Li et al., 2018; Zeithaml, 2002); create bonds with fellow members (Kozinets et al., 2010); help form a positive attitude towards the brand (Fournier, 1998); reveal passionate feelings towards a brand (Ahuvia, 2005); and rationalise to validate their decisions (Schau et al., 2009) - collectively enhancing brand community experience (Akar et al., 2019; Mathwick et al., 2008).

Such passionate behaviour is consistent with Baumeister et al.'s (1998) concept of an individual's "defence mechanism", which includes the protection of self-esteem. Loyal consumers consider these brands as an extension to their self-image (McAlexander et al., 2002) and do not hesitate to exhibit emotions to defend their brand decisions. To sum up, the results show that waiting is not only associated with negative outcomes, as previous research mostly proposed (Li et al., 2018; Mitsutomi and Kobayashi, 2012; Hui and Tse, 1996; Pruyn and Smidts, 1998), but also with positive consumer behaviours that may help develop stronger ties between the consumer and the brand.

In addition, several new value-creating behaviours are noticed within the context of customer-to-customer interactions during such prolonged delays confirming that these online communities are breeding grounds for new behaviours (Hassan and Casaló, 2016; Schau et al., 2009). To help these associates during such prolonged encounters, consumers provide information to the waiting customer by giving feedback, sympathising with them and persuading fellow associates to stick to the brand. Therefore, instead of joining complaints, many FBCs' members' behaviours serve to reduce the negative outcomes of other members having to wait, thereby supporting the idea that consumers in FBCs may implicitly help the brand (Hassan and Casaló, 2016). Such findings also confirm Thibaut and Kelley's (1959) social exchange theory that proposes that if the exchange is perceived to be beneficial, then the individual is likely to enter into an exchange relationship. As FBCs enhance the social life of many of its members, they reciprocate behaviour that is beneficial to other associates and overall to the brand, which maintains equity in their relationships as proposed by the equity theory (Steenhaut and Van Kenhove, 2005). Such brand community participation strengthens customer relationships with the brand and other customers and enhances customer loyalty (McAlexander et al., 2002). Hence, this study has contributed 


\begin{tabular}{|c|c|c|c|}
\hline Dimensions & Description & Example of coded statement & $S$ \\
\hline Whining & $\begin{array}{l}\text { Negative emotional } \\
\text { outburst following } \\
\text { lengthy wait. }\end{array}$ & $\begin{array}{l}\text { TW (M) Very frustrating, this is laughable. I placed my order in } \\
\text { March and am still waiting. If Ford can't even get this right, what } \\
\text { about something complex?? I am now getting seriously concerned } \\
\text { about the long term reliability of the car. August } 26,2010\end{array}$ & \\
\hline Quitting & $\begin{array}{l}\text { Leaving/intend to } \\
\text { leave the brand } \\
\text { following a long wait. }\end{array}$ & $\begin{array}{l}\text { AG (M) After NO uninitiated Ford or Dealer communication, I'll } \\
\text { be asking for my deposit back this week and putting my money } \\
\text { towards another (foreign) brand. I so wanted to buy an American } \\
\text { (albeit, Mexican) car. This whole experience has left a bad taste in } \\
\text { my mouth. What a shame, Ford- a damn shame. August 12, } 2010\end{array}$ & 417 \\
\hline Gossiping & $\begin{array}{l}\text { Spending time in } \\
\text { speculating the cause } \\
\text { behind the lengthy } \\
\text { wait. }\end{array}$ & $\begin{array}{l}\text { MS(M) Some in Ford forums have opined that the reason Fiestas } \\
\text { are being held up is due to a camshaft gasket oil leak problem. It } \\
\text { is only supposition, of course, but is floating around the 'net as } \\
\text { one possible reason. October } 16,2010\end{array}$ & \\
\hline Fantasising & $\begin{array}{l}\text { Vivid storytelling and } \\
\text { daydreaming while } \\
\text { waiting. }\end{array}$ & $\begin{array}{l}\text { BP (M) the Ford Fiesta is going to be my first car. I've been } \\
\text { driving my parents ' } 99 \text { bug for the past few years while saving } \\
\text { up. In July I went to my dealership and ordered a red SES with all } \\
\text { the goodies. Still waiting for the little bugger to get here even } \\
\text { though its been on the inventory of my dealership's site since the } \\
\text { beginning of July. Seems to keep getting pushed back and the } \\
\text { wait is killing me! Dealer called yesterday to tell me it should be in } \\
\text { this Sunday or sooner. . but personally I can't trust the ETAs } \\
\text { anymore! Anyways, I can't wait to drive in my first car and I'm } \\
\text { so happy its going to be a Ford :) August } 11,2010\end{array}$ & \\
\hline Loving & $\begin{array}{l}\text { Showing affection } \\
\text { towards the new car } \\
\text { after waiting } \\
\text { passionately. }\end{array}$ & $\begin{array}{l}\text { SH (F) It happened yesterday. Around 7:30pm. I drove off the } \\
\text { dealer lot with a } 2011 \text { Ford Fiesta SES with the Lightning Blue } \\
\text { Metallic paint. I'm parked on the street here at work with the } \\
\text { studio window overlooking my beautiful Fiesta. I couldn't be } \\
\text { happier. All I need to do now is name her. December 14, 2010. } \\
\text { KM(F) My Fiesta that I was told had no VIN/hadn't been made arrived } \\
\text { at the dealership today! Ford has no clue what they're doing. Somehow, } \\
\text { when I saw my new car (Magenta SES w/ moonroof), all of the anger } \\
\text { melted. I adore my car and I've only driven it } 20 \text { miles. August 6, } 2010\end{array}$ & \\
\hline Justifying & $\begin{array}{l}\text { Rationalising the } \\
\text { decision to cope with } \\
\text { the delay. }\end{array}$ & $\begin{array}{l}\text { CB(M) That really sucks, but sounds very common, a lot of people } \\
\text { here have had their Fiestas delayed for months past the delivery } \\
\text { dates. That's what the } \$ 50 \text { was for, everyone got it. I got the card, } \\
\& \text { I had one of the first cars in the States. . August } 27,2010\end{array}$ & \\
\hline Informing & $\begin{array}{l}\text { Helping the stranded } \\
\text { consumers by } \\
\text { providing } \\
\text { information to locate } \\
\text { the product. }\end{array}$ & $\begin{array}{l}\text { NG (M) Well if u can't wait and if u r In Nashville go to crown } \\
\text { ford they have some hatchbacks and ask for the cowboy Lee } \\
\text { Garanger. He helped me out a lot! I waited } 3 \text { weeks for my car too } \\
\text { and I was about to die because I sold my car. So I feel for the } \\
\text { people who actually r waiting longer. Also Clarksville too has a } \\
\text { sedan and a black hatchback. August 14, } 2010\end{array}$ & \\
\hline Counselling & $\begin{array}{l}\text { Comforting the } \\
\text { stranded consumers } \\
\text { while they wait. }\end{array}$ & $\begin{array}{l}\mathrm{SM}(\mathrm{F}) \text { I ordered mine in April, just came in last Monday. Build date 5/ } \\
10 \text { took } 3 \text { months to get it to Pa. There were hurricanes and tropical } \\
\text { storms they had to send them over on ships instead of by train. Did } \\
\text { you get a letter from Ford? Worth the wait! August 23, } 2010\end{array}$ & \\
\hline Motivating & $\begin{array}{l}\text { Persuading stranded } \\
\text { members to stick to } \\
\text { the brand. }\end{array}$ & $\begin{array}{l}\mathrm{CM}(\mathrm{F}) \text { Alexis- My experience was quite the opposite. The fiesta } \\
\text { really is a great little car, and I've been waiting two years since I } \\
\text { first saw it at the Auto Show in Detroit. . It was worth the wait } \\
\text { (and a lengthy time without ANY car!) Try contacting Ford } \\
\text { directly or perhaps speaking to the dealership manager, as } \\
\text { opposed to just a salesperson? August 13, } 2010\end{array}$ & $\begin{array}{r}\text { Table } \mathbf{1 .} \\
\text { Dimensions and data } \\
\text { examples }\end{array}$ \\
\hline
\end{tabular}




\begin{tabular}{ll}
\hline Dimensions & Description \\
\hline Caregiving & $\begin{array}{l}\text { Showing compassion } \\
\text { to reduce emotional } \\
\text { pain. }\end{array}$
\end{tabular}

\section{8}

Instilling fear in the minds of the waiting consumers in order to make them stick to the brand.

Defending

Cheerleading
Putting the blame on uncontrollable natural hazards to soothe the waiting customer Narrating vivid stories to reassure the waiting customers and motivate them to stick to the brand.
Example of coded statement

MGV(M) I hear ya (you) Gary. Mine was built the first week of June and still sits in Mexico according to Ford and my dealer. I live in northern New York and mine is still sitting in Mexico. I guess if you ordered first its not a first come first serve situation. I even preordered in December, December 5th to be exact. Mine is a Fiesta Hatch SES Lime Squeeze fully loaded basically. I am having Fiesta withdrawals and want my baby now. ... June 27, 2010

$\mathrm{KD}(\mathrm{F}) \mathrm{I}$ 'll be honest, maybe I had a bad experience but I considered waiting for the Fiesta and went with the Fit Sport instead and I kind of hate it. Bad time with the dealer and car developed door and dash rattles at 100 miles (which Honda won't fix because it's "acceptable" noise). I'm almost considering selling it off and getting a Fiesta and taking the $\$ 2000$ hit or whatever.... August 11, 2010

SM (F) There was a hurricane that washed out all the railroads. . .it's not Ford's fault, I'm in the same boat. But good news: www.freep.com/article/20100804/BUSINESS01/8040482/ Ford-nearly-back-on-track-with-Fiesta-delivery-after-storm Just thought I'd share. Good luck! August 5, 2010

SD (M) Figured this place would dig this. . .so my girlfriend and I are running errands Friday night (in the Fiesta of course). We're leaving one of our destinations and in the parking lot sits the VW GTI stalking the Blue Fame beauty sitting in the back side of the parking lot. The best part is they didn't see us walking up to the car and when we went to unlock the doors and the lights flew up, the startling encounter revealed their lustful desire for a cheaper, more fuel efficient, and better-looking car. They then zoomed off the lot in an attempt to cloak the reality they were just caught "checking out" the Fiesta. I'm not much for gloating (though I'd completely understand if you didn't believe that after this post), but Ford should be proud of the product out there. People are taking notice and I couldn't be happier with the little car, even if it did take 6 months to get the keys. October 11, 2010.

$\mathrm{KC}(\mathrm{F})$ Got my Fiesta. It was worth the wait. ... All I can say is that it is a great little car. Plenty of room, plenty of pep, way cute. The interior is fabulous and it's the little things about the car that are really impressive. Well thought out. Way to go Ford. So be patient peoples. You will get yours soon enough and will be very pleased :) August 4, 2010

significantly towards the knowledge of consumers' waiting behaviour in the context of customer-to-customer interactions within online communities.

This study also identified three new behaviours that were not noticed in previous literature. Specifically, consumers cultivate fear appeal to appease the switcher, defend the brand to offset the negative remarks of a waiting consumer and reassure the waiting consumers. These consumers are brand fanatics (Belk, 2004; Pimentel and Reynolds, 2004) who surpass the mainstream loyalty framework where their commitment reaches an extreme level that is strong, self-sustaining and virtually permanent (Oliver, 1999). Perhaps, the lengthy time associated in goods-based products (within Ford Fiesta, it is noticed that many consumers had to wait up to ten months after pre-ordering) is the reason behind such a diverse range of behaviours within the context of waiting. 
It is important to indicate that defending the brand to offset the negative remarks has never been reported within the context of waiting behaviour. This study has enriched the body of knowledge by showing evidence of such behaviour practised within online SNSs. Such findings are consistent with Fournier's (1998) "love and passion" facet of brand relationship quality, which reflects more than a strong preference for the brand. Rather, it is a feeling that the brand is irreplaceable and unique. This is also consistent with Ahuvia's (2005) remark of brand love, which does comprise not only passion for the brand, but also the positive evaluation of the brand. Furthermore, the findings of this study suggest that some members ("the cheerleaders") relay vivid stories of consumption experience to cheer the waiting consumers and try to assure, support and encourage the waiting crowd to stick to the brand and wait until the product is delivered. Such stories depicting members' superior product experience following the long wait should reduce the anxiety and stress of the associates who are waiting for the product, making waiting seem shorter and comforting (Jones and Peppiatt, 1996).

In sum, this work finds 13 consumer waiting behaviours within FBCs and confirms that waiting is not only associated with negative outcomes (e.g. frustration, boredom, etc.), but also to positive ones (e.g. create stronger ties with the brand and fellow members, etc.). Fellow members of FBCs are found to reduce consumer anxiety and stress during the waiting period, supporting the idea that new value-creating behaviours are noticed within the context of FBCs.

Managerially, what is most apparent from our findings is that consumers appear to be using brand attachments to engage themselves with new behaviours further. In this case, persuading and cheering the waiting consumers to reduce boredom and make them stick to the brand. Managers potentially have a very important way of strengthening their brand's equity if they can harness this motivation. Specifically, the various persuading roles observed in our findings are particularly compelling to managers looking for a credible response to complaints developed following a lengthy wait. In this respect, Hassan and Casaló (2016) noted how brand community members take actions to defend the brand and its image and insulate brands from negative events. Therefore, the identification of these new behaviours adds strength to the arm of those making a case for online brand communities as a key component of brand strategy (Akar et al., 2019). All these suggest that managers should motivate consumers to be part of online brand communities and cultivate a strong consumer identification and attachment to the brand to benefit from consumers' positive reaction to waiting scenarios. For example, Ford Fiesta's FBC site may run a "member of the month" programme where a member will be chosen every month for his or her positive role and effort towards another member of the site. A range of positive behaviours should be recognised, and the member's name should be written on the wall of the FBC site so that everyone can identify the member. An online ceremony can be held to recognise the members' role, and Ford goodies and memorabilia can be offered to commemorate the positive behaviour. This will surely encourage more positive behaviour, and members' will be motivated to achieve such a feat.

Furthermore, members are not only cheering up the waiting consumers but also persuading and preventing them from buying competitors' brands, prompting a suggestion that such roles should be delegated to them. Although many well-known companies are implementing best practices in response to this new form of complaining via social media (Grégoire et al., 2015), marketers should be open to such engagement and empower consumers to fulfil this role first (as interpersonal communication is considered as more trustworthy (Jeong and Koo, 2015). However, management should keep a close eye on the dialogues within their virtual communities to ensure its effectiveness. This study, thus, 
suggests that important transition is taking place within marketing as far as the roles of the different actors are concerned, which places enormous challenges and burdens on both the parties.

\subsection{Limitations and future research lines}

Despite the interesting results, this research has some limitations that open future research avenues. First of all, this study has analysed waiting behaviours in just one FBC focused on the Ford Fiesta. As this is a high involvement product (automobile), it may be a good idea to investigate other FBCs focused on low involvement products or even in services. In addition, the data for this study was collected in 2010. Future studies may consider more recent data to validate the findings of this paper. Furthermore, it is clear that waiting behaviours may vary due to consumers' characteristics. For example, we may expect that more collectivistic (rather than individualistic) consumers will be less likely to complain because they emphasise social harmony (Wan, 2013). Therefore, it would be interesting to shed light on this issue and analyse waiting behaviours in FBCs, including consumers from different cultures and nationalities. Even the consumer narrative style may be crucial to attracting fellow members (Kozinets et al., 2010). It could be useful to analyse whether different narrative styles could motivate different waiting behaviours.

\section{References}

Ahuvia, A.C. (2005), "Beyond the extended self: loved objects and consumers' identity narratives", Journal of Consumer Research, Vol. 32 No. 1, pp. 171-184.

Akar, E., Mardikyan, S. and Dalgic, T. (2019), "User roles in online communities and their moderating effect on online community usage intention: an integrated approach", International Journal of Human - Computer Interaction, Vol. 35 No. 6, pp. 495-509.

Aksin, Z., Ata, B., Emadi, S. and Su, C. (2013), "Structural estimation of callers' delay sensitivity in call centers", Management Science, Vol. 59 No. 12, pp. 2727-2746.

Andersen, P.H. (2005), "Relationship marketing and brand involvement of professionals through webenhanced brand communities: the case of Coloplast", Industrial Marketing Management, Vol. 34 No. 1, pp. 39-51.

Antonides, G., Verhoef, P.C. and van Aalst, M. (2002), "Consumer perception and evaluation of waiting time: a field experiment”, Journal of Consumer Psychology, Vol. 12 No. 3, pp. 193-202.

Baker, J. and Cameron, M. (1996), "The effects of the service environment on affect and consumer perception of waiting time: an integrative review and research propositions", Journal of the Academy of Marketing Science, Vol. 24 No. 4, pp. 338-349.

Baumeister, R.F., Dale, K. and Sommer, K.L. (1998), "Freudian defense mechanisms and empirical findings in modern social psychology: reaction formation, projection, displacement, undoing, isolation, sublimation, and denial", Journal of Personality, Vol. 66 No. 6, pp. 1081-1124.

Becker, G.S. (1965), "A theory of the allocation of time”, The Economic Journal, Vol. 75 No. 299, pp. 493-517.

Belk, R.W. (2004), "Men and their machines”, Advances in Consumer Research, Vol. 31, pp. 273-276.

Belk, R.W., Ger, G. and Askegaard, S. (2003), “The fire of desire”, Journal of Consumer Research, Vol. 30 No. 3, pp. 326-351.

Berkowitz, L. (1989), "Frustration-aggression hypothesis: examination and reformulation", Psychological Bulletin, Vol. 106 No. 1, pp. 59-73.

Bielen, F. and Demoulin, N. (2007), "Waiting time influence on the satisfaction-loyalty relationship in services”, Managing Service Quality: An International Journal, Vol. 17 No. 2, pp. 174-193. 
Bryman, A. (2008), Social Research Methods, Oxford University Press, Oxford.

wCasaló, L.V., Flavián, C. and Guinalíu, M. (2011), "Understanding the intention to follow the advice obtained in an online travel community", Computers in Human Behavior, Vol. 27 No. 2, pp. 622-633.

Chebat, J.C., Filiatrault, P., Chebat, G.C. and Vaninsky, A. (1995), "Impact of waiting attribution and consumer's mood on perceived quality", Journal of Business Research, Vol. 34 No. 3, pp. 191-196.

Chen, R. and Jia, J. (2012), "Regret and performance uncertainty in consumer repeat choice", Marketing Letters, Vol. 23 No. 1, pp. 353-365.

Chien, S. and Lin, Y.T. (2015), "The effects of the service environment on perceived waiting time and emotions", Human Factors and Ergonomics and Service Industries, Vol. 25, pp. 319-328.

Colliander, J. and Wien, A.H. (2013), "Trash talk rebuffed: consumers' defense of companies criticised in online communities", European Journal of Marketing, Vol. 47 No. 10, pp. 1733-1757.

Dunay, P. and Krueger, R. (2011), Facebook Marketing for Dummies, Wiley and Sons, NJ.

Einwiller, S.A. and Steilen, S. (2015), "Handling complaints on social network sites - an analysis of complaints and complaint responses on Facebook and Twitter pages of large US companies", Public Relations Review, Vol. 41 No. 2, pp. 195-204.

Fournier, S. (1998), "Consumers and their brands: developing relationship theory in consumer research", Journal of Consumer Research, Vol. 24 No. 4, pp. 343-353.

Fournier, S. and Guiry, M. (1993), "An emerald green Jaguar, a house on Nantucket, and an African safari: wish lists and consumption dreams in materialist society", Advances in Consumer Research, Vol. 20, pp. 352-358.

Frasquet-Deltoro, M., Alarcón-del-Amo, M.-D.-C. and Lorenzo-Romero, C. (2019), "Antecedents and consequences of virtual customer co-creation behaviours", Internet Research, Vol. 29 No. 1, pp. 218-244.

Glaser, B.G. and Strauss, A.L. (1967), The Discovery of Grounded Theory: Strategies for Qualitative Research, Aldine, Chicago.

Goodwin, C., Smith, K.L. and Verhage, B.J. (1991), "An equity model of consumer response to waiting time", Journal of Consumer Satisfaction, Dissatisfaction, and Complaining Behavior, Vol. 4, pp. 129-138.

Grégoire, Y., Salle, A. and Tripp, T.M. (2015), "Managing social media crises with your customers: the good, the bad, and the ugly", Business Horizons, Vol. 58 No. 2, pp. 173-182.

Hassan, M. (2013), "Brand communities of Facebook: how do they create value?”, Doctoral Dissertation, Southern Cross University, available at: http://epubs.scu.edu.au/theses/404/ (accessed 29 November 2016).

Hassan, M. and Casaló, L.V. (2016), "Consumer devotion to a different height: how consumers are defending the brand within Facebook brand communities", Internet Research, Vol. 26 No. 4, pp. 963-981.

Herr, P.M., Kardes, F.R. and Kim, J. (1991), "Effects of word-of-mouth and product-attribute information on persuasion: an accessibility-diagnosticity perspective", Journal of Consumer Research, Vol. 17 No. 4, pp. 454-462.

Hochschild, A. (1979), "Emotion work, feeling rules, and social structure", American Journal of Sociology, Vol. 85 No. 3, pp. 551-575.

Hui, M.K. and Tse, D.K. (1996), "What to tell consumers in waits of different lengths: an integrative model of service evaluation”, Journal of Marketing, Vol. 60 No. 2, pp. 81-90.

Jeong, H.J. and Koo, D.M. (2015), "Combined effects of valence and attributes of e-WOM on consumer judgment for message and product: the moderating effect of brand community type", Internet Research, Vol. 25 No. 1.

Jones, P. and Peppiatt, E. (1996), "Managing perceptions of waiting times in service queues", International Journal of Service Industry Management, Vol. 7 No. 5, pp. 47-61. 
Korzeniewski, J. (2010), "Ford fiesta shipments delayed due to hurricane, damaged railroads, update", available at: www.autoblog.com/2010/07/13/ford-fiesta-shipments-delayed-due-to-hurricanedamaged-railroad/ (accessed 29 November 2016).

Kozinets, R.V. (2011), Netnography: Doing Ethnographic Research Online, Sage Publications, London.

Kozinets, R.V., De Valck, K., Wojnicki, A.C. and Wilner, S.J.S. (2010), "Networked narratives: understanding word-of-mouth marketing in online communities", Journal of Marketing, Vol. 74 $422 \quad$ No. 2, pp. 1-89.

Levesque, T.J. and McDougall, G.H.G. (2000), "Service problems and recovery strategies: an experiment”, Canadian Journal of Administrative Sciences/Revue Canadienne Des Sciences de L'administration, Vol. 17 No. 1, pp. 20-37.

Li, G., Huang, J.Z. and Shen, H. (2018), "To wait or not to wait: two-way functional hazards model for understanding waiting in call centers", Journal of the American Statistical Association, Vol. 113 No. 524, pp. 1503-1514.

Liang, C.C. (2019), "Enjoyable queuing and waiting time”, Time and Society, Vol. 28 No. 2, pp. 543-566, doi: 10.1177/0961463X17702164.

Liu, N., Finkelstein, S.R., Kruk, M.E. and Rosenthal, D. (2018), "When waiting to see a doctor is less irritating: understanding patient preferences and choice behavior in appointment scheduling", Management Science, Vol. 64 No. 5, pp. 1975-1996.

Lovelock, C. and Gummesson, E. (2004), "Whither services marketing? In search of a new paradigm and fresh perspectives", Journal of Service Research, Vol. 7 No. 1, pp. 20-41.

Lovelock, C. and Lapert, D. (1999), Marketing Des Services, Publications Union, Paris.

McAlexander, J.H., Schouten, J.W. and Koenig, H.F. (2002), "Building brand community", Journal of Marketing, Vol. 66 No. 1, pp. 38-54.

Mano, H. and Oliver, R.L. (1993), "Assessing the dimensionality and structure of the consumption experience: evaluation, feeling, and satisfaction”, Journal of Consumer Research, Vol. 20 No. 3, pp. 451-466.

Marandi, E., Little, E. and Hughes, T. (2010), "Innovation and the children of the revolution: Facebook and value co-creation", The Marketing Review, Vol. 10 No. 2, pp. 169-183.

Mathwick, C., Wiertz, C. and De Ruyter, K. (2008), "Social capital production in a virtual P3 community”, Journal of Consumer Research, Vol. 34 No. 6, pp. 832-849.

Mazzarol, T., Sweeney, J.C. and Soutar, G.N. (2007), "Conceptualising word-of-mouth activity, triggers and conditions: an exploratory study", European Journal of Marketing, Vol. 42, pp. 344-364.

Miles, M.B. and Huberman, A.M. (1994), Qualitative Data Analysis: An Expanded Sourcebook, Sage Publications, Beverly Hills.

Mitsutomi, T. and Kobayashi, S. (2012), "The effects of situational factors on the waiting behavior in adolescents", Kwassui Bulletin, Vol. 55, pp. 1-11.

Mogilner, C. and Aaker, J. (2009), "The time vs money effect': shifting product attitudes and decisions through personal connection”, Journal of Consumer Research, Vol. 36 No. 2, pp. 277-291.

Muñiz, A.M., Jr and O'guinn, T.C. (2001), "Brand community”, Journal of Consumer Research, Vol. 27 No. 4, pp. 412-432.

Muñiz, A.M., Jr and Schau, H.J. (2005), "Religiosity in the abandoned Apple Newton brand community", Journal of Consumer Research, Vol. 31 No. 4, pp. 737-747.

Oettingen, G. (2012), "Future thought and behavior change", European Review of Social Psychology, Vol. 23 No. 1, pp. 1-63.

Oliver, R.L. (1999), “Whence consumer loyalty?”, Journal of Marketing, Vol. 63 No. 4_suppl1, pp. 33-44.

Osadchiy, N. and Diwas, K.C. (2017), "Are patients patient? The role of time to appointment in patient flow”, Production and Operations Management, Vol. 26 No. 3, pp. 469-490. 
Pagani, M., Hofacker, C.F. and Goldsmith, R.E. (2011), "The influence of personality on active and passive use of social networking sites", Psychology and Marketing, Vol. 28 No. 5, pp. 441-456.

Paglieri, F. (2013), "The costs of delay: waiting versus postponing in intertemporal choice", Journal of the Experimental Analysis of Behavior, Vol. 99 No. 3, pp. 362-377.

Pfeffer, J., Zorbach, T. and Carley, K.M. (2014), "Understanding online firestorms: negative word-ofmouth dynamics in social media networks", Journal of Marketing Communications, Vol. 20 Nos 1/2, pp. 117-128.

Pimentel, R.W. and Reynolds, K.E. (2004), “A model for consumer devotion: affective commitment with proactive sustaining behaviors", Academy of Marketing Science Review, Vol. 5, pp. 1-45.

Priharsari, D., Abedin, B. and Mastio, E. (2020), "Value co-creation in firm sponsored online communities: what enables, constrains, and shapes value", Internet Research, Vol. 30 No. 3, doi: 10.1108/INTR-05-2019-0205.

Pruyn, A. and Smidts, A. (1993), "Customers' evaluations of queues: three exploratory studies", European Advances in Consumer Research, Vol. 1, pp. 371-382.

Pruyn, A. and Smidts, A. (1998), "Effects of waiting on the satisfaction with the service: beyond objective time measures", International Journal of Research in Marketing, Vol. 15 No. 4, pp. 321-334.

Raban, D.R. and Rafaeli, S. (2007), "Investigating ownership and the willingness to share information online", Computers in Human Behavior, Vol. 23 No. 5, pp. 2367-2382.

Rafaeli, A., Barron, G. and Haber, K. (2002), "The effects of queue structure on attitudes", Journal of Service Research, Vol. 5 No. 2, pp. 125-139.

Schau, H.J., Muñiz, A.M., Jr and Arnold, E. (2009), "How brand community practices create value", Journal of Marketing, Vol. 73 No. 5, pp. 30-51.

Schiffman, L. and Kanuk, L. (2014), Consumer Behaviour, Pearson education, London.

Simonson, I. (1989), "Choice based on reasons: the case of attraction and compromise effects", Journal of Consumer Research, Vol. 16 No. 2, pp. 158-174.

Spiggle, S. (1994), "Analysis and interpretation of qualitative data in consumer research", Journal of Consumer Research, Vol. 21 No. 3, pp. 491-503.

Sproull, L., Conley, C.A. and Moon, J.Y. (2005), "Prosocial behaviour on the net", in Amichai-Hamburger, Y. (Ed.), The Social Net: understanding Human Behaviour in Cyberspace, Oxford University Press, New York, NY.

Steenhaut, S. and Van Kenhove, P. (2005), "Relationship commitment and ethical consumer behavior in a retail setting: the case of receiving too much change at the checkout", Journal of Business Ethics, Vol. 56 No. 4, pp. 335-353.

Stidham, S. Jr (2009), Optimal Design of Queueing Systems, CRC Press, Taylor and Francis Group, Boca Raton.

Sweeney, J.C., Soutar, G.N. and Mazzarol, T. (2012), "Word of mouth: measuring the power of individual messages", European Journal of Marketing, Vol. 46 Nos 1/2, pp. 237-257.

Taylor, S. (1995), "The effects of filled waiting time and service provider control over the delay on evaluations of service", Journal of the Academy of Marketing Science, Vol. 23 No. 1, pp. 38-48.

Thibaut, J.W. and Kelley, H.H. (1959), The Social Psychology of Groups, Wiley and Sons, New York, NY.

Thompson, C.J., Pollio, H.R. and Locander, W.B. (1994), "The spoken and the unspoken: a hermeneutic approach to understanding the cultural viewpoints that underlie consumers' expressed meanings", Journal of Consumer Research, Vol. 21 No. 3, pp. 432-452.

Usunier, J.C. and Valette-Florence, P. (2007), "The time styles scale: a review of developments and replications over 15 years", Time and Society, Vol. 16 Nos 2/3, pp. 333-366.

Wan, L.C. (2013), "Culture's impact on consumer complaining responses to embarrassing service failure", Journal of Business Research, Vol. 66 No. 3, pp. 298-305. 
SJME

24,3

Weiner, B. (1980), "May I borrow your class notes? An attributional analysis of judgments of help giving in an achievement-related context", Journal of Educational Psychology, Vol. 72 No. 5, pp. 676-681.

Wiertz, C. and De Ruyter, K. (2007), "Beyond the call of duty: why customers contribute to firmhosted commercial online communities", Organization Studies, Vol. 28 No. 3, pp. 347-376.

Wu, G. (1999), "Perceived interactivity and attitude toward web sites", Paper presented at the Annual Conference of American Academy of Advertising, Albuquerque, NM.

Yen, H.J.R., Hsu, S.H.Y. and Huang, C.Y. (2011), "Good soldiers on the web: understanding the drivers of participation in online communities of consumption", International Journal of Electronic Commerce, Vol. 15 No. 4, pp. 89-120.

Zeithaml, V.A. (2002), "Service excellence in electronic channels", Managing Service Quality: An International Journal, Vol. 12 No. 3, pp. 135-139.

\section{Corresponding author}

Rumman Hassan can be contacted at: Rumman.Hassan@usq.edu.au

For instructions on how to order reprints of this article, please visit our website: www.emeraldgrouppublishing.com/licensing/reprints.htm

Or contact us for further details: permissions@emeraldinsight.com 